\title{
Trauma Kepala pada Anak: Klasifikasi Hingga Pemantauan Jangka Panjang
}

\author{
Erny $^{1}$, Okky Prasetyo ${ }^{2}$, Denny Prasetyo ${ }^{3}$ \\ ${ }^{1}$ Pediatric department of medical faculty Wijaya Kusuma University Surabaya \\ ${ }^{2}$ Fakultas Kedokteran Universitas Ciputra \\ ${ }^{3}$ Rumah Sakit Umum Muhammadiyah Gresik
}

\begin{abstract}
Abstrak
Trauma kepala pada anak sering terjadi akibat jatuh, permainan, kecelakaan lalin dan sebab lainnya. Tidak seluruh trauma kepala berlanjut menyebabkan cedera otak. Sehubungan dengan hal tersebut dokter wajib mengetahui diagnosis trauma kepala, mengkalsifikasikan agar dapat ditentukan derajat trauma kepala yang digunakan untuk menentukan tatalaksana dan meramalkan hasil luaran terutama yang berkaitan dengan masalah tumbuh kembang anak. Pengamatan jangka panjang pasca trauma kepala harus dilakukan terutama pada trauma kepala derajat sedang hingga berat untuk mendeteksi secara dini dan berkelanjutan setiap kelainan perkembangan anak
\end{abstract}

Kata Kunci: trauma kepala anak, klasifikasi, pengamatan jangka panjang

\section{Head Trauma in Children: Classification and Long-Term Monitoring}

\begin{abstract}
Head trauma in children are frequent caused by falling, games, traffic accidents and more. Not all of head trauma continues to be brain injury. According with this, all of doctor must be able to established the diagnosis and classified head trauma to determine the optimal management and prognosis especially related with problems of brain development after head trauma. Longterm follow up should be done especially in severe and moderate head trauma to early detection any problems about development progress in this child.
\end{abstract}

Keywords: head trauma in children, classification, long-term follow up

\section{PENDAHULUAN}

Trauma kepala yang menyebabkan cedera otak adalah salah satu bentuk cedera otak non degenerative yang disebabkan oleh benturan, pukulan, ataupun hentakan mendadak pada kepala atau suatu luka tembus di kepala yang mengganggu fungsi otak normal (Centers for Disease Control and Prevention, 2015). Cedera otak karena trauma pada anakanak adalah salah satu dari penyebab kematian terbanyak. Menurut Bruce et al (1996), 300.000- 400.000 anak di amerika serikat dibawa ke rumah sakit karena cedera kepala setiap tahunnya, dengan angka kematian mencapai 6000- 7000 anak 
Trauma Kepala pada Anak: Klasifikasi Hingga Pemantauan jangka Panjang

Erny, Okky Prasetyo, Denny Prasetyo

di usia $<14$ tahun. Sementara di Australia, menurut Mitra et al (2007), terdapat angka kejadian 765 dari 100.000 per tahun, dimana $40 \%$ memerlukan tindakan operasi. Data dari riskesdas tahun 2013 menunjukkan angka kejadian cedera kepala pada anak sekitar $0,5 \%$ populasi dari angka cidera yang lain.

Menurut Mihic et al (2011) penyebab trauma kepala pada anak- anak yang terbanyak adalah karena jatuh dan kecelakaan lalu lintas. Pada usia kurang dari 1 tahun, tersering adalah jatuh dari gendongan, tempat tidur dan tempat bermain, trauma kepala ini relatif ringan dan jarang memerlukan tindakan spesifik. Trauma kepala yang lebih berat dapat disebabkan oleh guncangan pada kepala yang berakibat fatal yang dikenal dengan Shaken baby syndrome dan kekerasan dalam rumah tangga yang dapat menyebabkan perdarahan subdural dan membutuhkan penanganan yang spesifik. Pada usia yang lebih besar, insiden jatuh dari ketinggian ataupun kecelakaan akan meningkat.

Perbedaan yang nyata dengan trauma kepala pada dewasa adalah pada anak masih terjadi proses perkembangan otak sehingga trauma kepala yang berlanjut menjadi cedera otak merupakan proses kronis progresif yang berisiko menyebabkan gangguan tumbuh kembang dari berbagai aspek (De Pompei et al, 2010) berdasarkan hal tersebut perlu pemantauan jangka panjang.

\section{KLASIFIKASI TRAUMA KEPALA}

Klasifikasi trauma kepala dilakukan untuk menentukan tatalaksana dan meramalkan hasil luarannya. Klasifikasi terdiri dari beberapa jenis tergantung aspek yang mendasarinya. Berdasarkan derajat keberatannya, trauma kepala diklasifikasikan menjadi trauma kepala ringan, sedang dan berat. Klasifikasi trauma kepala berdasarkan etiologinya dibagi menjadi cedera primer dan cedera sekunder. Klasifikasi lain berdasarkan dari tingkat keparahan trauma kepala, adanya luka diluar kepala, gangguan kesadaran atau memori pasca trauma, trauma kepala dibagi menurut GCS yang sudah dimodifikasi (Malec, 2007). 
ISSN 1978-2071 (Print); ISSN 2580-5967 (Online) Jurnal IImiah Kedokteran Wijaya Kusuma 8(2) : 42-58, September 2019

\section{Modified Glasgow Coma Scale for Infants and Children}

\begin{tabular}{|l|l|l|l|}
\hline & Child & Infant & Score \\
\hline Eye opening & Spontaneous & Spontaneous & 4 \\
& To speech & To speech & 3 \\
& To pain only & To pain only & 2 \\
& No response & No response & 1 \\
\hline Best verbal & Oriented, appropriate & Coos and babbles & 5 \\
response & Confused & Irritable cries & 4 \\
& Inappropriate words & Cries to pain & 3 \\
& Incomprehensible sounds & Moans to pain & 2 \\
& No response & No response & 1 \\
\hline \multirow{2}{*}{ Best motor } & Obeys commands & Moves spontaneously and & 6 \\
& Localizes painful stimulus & purposefully & 5 \\
& Withdraws in response to & Withdraws to touch & 4 \\
& pain & Withdraws to response in pain & 3 \\
& Flexion in response to pain & Abnormal flexion posture to pain & 2 \\
& Extension in response to & Abnormal extension posture to pain & 1 \\
& pain & No response & \\
& No response & & \\
\hline
\end{tabular}

*If patient is intubated, unconscious, or preverbal, the most important part of this scale is motor response. Motor response should be carefully evaluated.

Berdasarkan dari nilai GCS saat kejadian

otak pada anak oleh Brasure et al (2012)

akut serta gejala penyerta, maka cedera

terbagi menjadi:

Derajat Trauma kepala

\begin{tabular}{llll}
\hline Kriteria & Ringan & Sedang & Berat \\
Pencitraan & normal & normal atau abnormal & normal atau abnormal \\
Hilang kesadaran & $<30$ menit & 30 menit hingga 24 jam & $>24$ jam \\
Amnesia pasca trauma & $0-1$ hari & $>1$ dan $<7$ hari & $>7$ hari \\
Skala koma Glascow & $13-15$ & $9-12$ & $3-8$ \\
abbreviated injury scale score: kepala & $1-2$ & 3 & $4-6$
\end{tabular}

\section{PENDEKATAN DIAGNOSIS}

Untuk menegakkan diagnosis,
tatalaksana dan menentukan prognosa,
memerlukan serangkaian anamnesa,
pemeriksaan fisik umum dan pemeriksaan
neurologi dan pemeriksaan penunjang jika
diperlukan.

Anamesa yang perlu digali meliputi:

1. Mekanisme trauma, ketinggian jatuh, alas saat jatuh dan posisi tubuh saat jatuh. Jika trauma kepala akibat kecelakaan lalin perlu ditanyakan apakah anak menggunakan pelindung kepala, apakah anak terlempar jika terjadi sampai setinggi apa, jika terseret posisi kepala dimana apakah jatuh pada posisi kepala dibawah atau tidak.

2. Kesadaran anak setelah kejadian trauma kepala apakah anak masih 
sadar baik, menangis atau tidak, untuk anak yang sudah bisa berbicara apakah anak masih merespon pertanyaan atau tidak dan jika terjadi gangguan kesadaran berapa lama terjadi.

3. Apakah ada cedera ganda dibagian tubuh yang lain dan seberapa parah dan apakah terjadi perdarahan yang masif. Setelah kejadian trauma apakah anak masih mengingat orang tuanya, lokasi kecelakaan dan pada anak yang relatif sudah besar apakah masih mengingat mekanisme kecelakaan.

4. Apakah ada muntah spontan yang terjadi tanpa sebab lainnya

5. Nyeri kepala hebat

6. Perdarahan dari hidung, telinga atau mulut.

7. Kejang spontan saat trauma atau beberapa saat setelah trauma kepala.

8. Apakah terjadi perubahan perilaku anak yang bermakna setelah trauma dan apakah ada gangguan pola tidur pasca trauma.

9. Riwayat tumbuh kembang anak hingga saat trauma kepala terjadi untuk menentukan potensi awal anak.

Keseluruhan anamnesa perlu digali dengan cermat disamping juga perlu dipikirkan kemungkinan penyebab child abuse yang memunculkan gejala serupa.
Pemeriksaan fisik:

1. pemeriksaan tanda vital, tekanan darah, nadi respirasi dan derajat kesadaran sesuai dengan skala koma glasgow pediatrik untuk stabilisasi segera untuk kelangsungan hidup dasar.

2. Status mental dievaluasi apakah anak masih menangis, responsif atau diam, gaduh gelisah hingga agitasi.

3. Status lokalis trauma perlu diperinci dengan cermat misalnya jika ada benjolan, lokasi, besar, rasa nyeri, berdenyut atau tidak (pulsatif).

4. Kepala:

a. Jejas trauma apakah ada hematoma, lacerasi, luka terbuka, depresi tulang, gigi patah atau tanggal

b. Cairan yang keluar melalui telinga, hidung dan mulut, battle sign, racoon eyes.

c. Wajah asimetris atau tidak.

d. Refleks pupil isokor atau anisokor, diameter pupil dan refleks cahaya.

e. Evaluasi nervi cranialis apakah ada lateralisasi atau tidak.

5. Leher:

a. Jejas trauma, lokasi, jika ada secepatnya harus dilakukan stabilisasi dan imobilisasi untuk mencegah cedera baru akibat perlakuan. 
b. Kaku kuduk jika dicurigai terjadi kebocoran cairan serebrospinal tetapi terdapat jejas diseputar leher maka pemeriksaan meningeal sign dapat dilakukan ditempat lain misalnya memeriksa tanda kerniq atau laseque.

6. Pemeriksaan jejas diluar kepala yang berpotensi menyebabkan perdarahan baik yang nyata atau perdarahan internal.

7. Pemeriksaan sensorimotor untuk menilai pergerakan apakah masih spontan, simetris dan terkoordinasi dengan baik atau tidak. Pemeriksaan refleks fisiologis, patologis untuk menilai keterlibatan parenkim otak.

\section{PEMERIKSAAN PENUNJANG}

Pemeriksaan penunjang diindikasikan pada trauma kepala derajat sedang berat. Pemeriksaan penunjang meliputi pemeriksaan laboratorium yang terdiri dari pemeriksaan darah lengkap, serum elektrolit, gula darah dan S100B/calcium-binding protein B (biomarker yang menunjukkan kerusakan sel otak). Pemeriksaan penunjang lainnya adalah radiologis yang terdiri dari CT Scan kepala atau MRI kepala dan pemeriksaan EEG.

Pemeriksaan darah lengkap untuk mengevaluasi penurunan kadar $\mathrm{Hb}$ dan
PCV (Packed Cell Volume) terutama pada trauma kepala dengan perdarahan masif. Kondisi anemia harus diwaspadai mengingat hemoglobin sebagai molekul pengangkut oksigen harus dijaga kecukupannya untuk mencegah terjadinya hipoksia yang akan menyebabkan cedera otak sekunder akibat kerusakan mekanisme autoregulasi pembuluh darah otak yang menyebabkan tekanan darah diotak akan sangat tergantung pada tekanan darah sistemik (Brain Trauma Foundation, 2007).

Keterkaitan antara jumlah lekosit darah tepi dengan berbagai penyakit pada sistem saraf pusat yang berkaitan dengan proses inflamasi sudah dievaluasi sejak tahun 1896. Menghitung rasio Netrofil terhadap limfosit (RNL) adalah salah satu petanda yang mudah dilakukan. Penelitian secara umum mendapatkan adanya peningkatan jumlah netrofil yang besamaan dengan penurunan jumlah limfosit segera setelah terjadi cedera jaringan termasuk pada cedera otak. Penelitian sebelumnya juga menemukan keterkaitan antara RNL dengan cedera iskemik cerebral (Merlin et al, 2018). Peningkatan jumlah lekosit darah tepi terutama netrofil mengindikasikan terjadi respon inflamasi pasca trauma kepala minor pada anak (Rovlias et al, 2001). Hasil penelitian tersebut mengesankan bahwa 
Trauma Kepala pada Anak: Klasifikasi Hingga Pemantauan jangka Panjang

Erny, Okky Prasetyo, Denny Prasetyo

stress karena trauma dapat menyebabkan demarginasi lekosit yang nyata walaupun trauma kepala yang terjadi bukan tergolong berat. Pada penelitian lanjutan ditemukan korelasi positif antara lekosit dan kadar neutrofil dengan derajat keberatan trauma dan skor Acute Ischaemic Stroke (AIS). Rovlias et al melaporkan bahwa pasien dengan trauma kepala berat secara bermakna menunjukkan peningkatan lekosit secara bermakna dibanding dengan trauma kepala derajat sedang - ringan. Peningkatan jumlah lekosit merupakan akibat dari peningkatan kortisol dan katekolamin yang terjadi pada trauma kepala dan semakin tinggi jumlah lekosit pada saat pasien masuk RS merupakan presenden keburukan prognosis (Rovlias et al, 2001).

Evaluasi trombosit juga menunjukkan hubungan yang erat dengan derajat trauma kepala, skor GCS, hasil luaran klinis dan lama tinggal di RS. Validitas trombositopenia digunakan sebagai faktor prediktor untuk keburukan prognosis setelah trauma kepala dengan spesifisitas $77,4 \%$, Odd's rasio 3,1 , risiko relatif 2,15 (Kamal et al, 2011). penurunan jumlah rata rata trombosit secara paralel terjadi sesuai dengan derajat trauma kepala (Lippi et al, 2013). Hal tersebut terjadi akibat karena terjadi peningkatan konsumsi trombosit secara bermakna pada tempat migrasi lekosit segera setelah trauma kepala. Hubungan terbalik dilaporkan antara jumlah trombosit dan Mean Platelet Volume (MPV) pada kondisi fisiologis dan patologis untuk memelihara hemostasis dengan menjaga kestabilan jumlah trombosit (Turfan et al, 2013). Peneliti menekankan bahwa hasil rasio MPV/N untuk identifikasi derajat trauma dapat digunakan sebagai parameter untuk merencanakan tindakan pemeriksaan lanjutan (Berksoy and Anil, 2019).

Komplikasi sistemik terutama disebabkan oleh kondisi hipoksemia, hipotensi, hipertensi, hiperglikemia dan hipoglikemia [Jeremitsky et al, 2003). Diantara komplikasi sekunder tersebut, hiperglikemia merupakan salah satu hal yang sering terjadi dan berhubungan dengan derajat cedera dan hasil luaran pasien [Rovlias and Kotsou, 2000). Beberapa penelitian sebelumnya menunjukkan bahwa hiperglikemia berperan penting dalam mempercepat keburukan hasil klinis pada trauma kepala. Mekanisme yang memicu terjadinya hiperglikemia setelah trauma kepala adalah respon akibat strees fisik, respon inflamasi, diabetes mellitus, disfungsi kelenjar pituitary dan atau hipothalamus, pembedahan dan anestesia. Pasien trauma kepala dengan hiperglikemia memiliki 
ISSN 1978-2071 (Print); ISSN 2580-5967 (Online) Jurnal IImiah Kedokteran Wijaya Kusuma 8(2) : 42-58, September 2019

peningkatan risiko perburukan hasil luaran dan kematian lebih nyata dengan kondisi hiperglikemia persisten dibanding dengan hiperglikemia sesaat setelah trauma (Seyed et al, 2012). Efek langsung lainnya akibat hiperglikemia adalah asidosis laktat, gangguan keseimbangan elektrolit, inflamasi, penyakit pembuluh darah, kerusakan SDO dan hiperpermeabilitas (Shi et al, 2016).

Gangguan keseimbangan elektrolit yang terjadi setelah trauma kepala merupakan salah satu hal yang harus dimonitor. Natrium adalah elektrolit utama yang harus dimonitor disamping Kalium, Caksium dan fosfat. Berdasarkan dari hasil CT Scan kepala beberapa kasus trauma kepala berhubungan dengan berbagai gangguan keseimbangan elektrolit yang secara khusus terjadi dalam 24 jam pertama setelah resusitasi (Suman et al, 2016). Elektrolit yang sering mengalami kekacauan adalah kadar Natrium dan kalium serum yang terjadi secara sekunder akibat resusitasi dan terapi farmakologi (penggunaan furosemid dan manitol). Penggantian volume dengan cairan isotonik tidak hanya memiliki efek terapi yang terbatas tetapi dapat memperberat edema otak pasca trauma kepala (Berger et al, 1994). Hiponatremia juga dapat disebabkan oleh Syndrome of Inappropriate Antidiuretic Hormone
Secretion (SIADH). Penelitian yang menyimpulkan bahwa ANP (Atrial naturetic peptide) berperan penting menyebabkan hiponatremia pada pasien dengan Subarachnoid haemorrhagic (SAH) dengan terjadi ekkresi masif natrium dan air. Peningkatan ekskresi urine terjadi akibat inhibisi dari proses reabsorbsi natrium di ginjal. Pasien dengan truma kepala berat juga memiliki risiko tinggi terjadi hipokalemia, hal ini diduga berkaitan dengan peningkatan pengeluaran urine. Perubahan kalsium serum menyebabkan beberapa manifestasi klinis yang pada awalnya menyebabkan tetani hingga kejang. Hal ini akibat respon abnormal neuron terhadap akumulasi kalsium intraseluler pada trauma kepala. Keseluruhan gangguan keseimbangan elektrolit harus dipantau untuk mencegah terjadinya gangguan otak sekunder.

Pemeriksaan S100B dianjurkan untuk mengurangi penggunaan CT Scan kepala untuk menurunkan risiko radiasi yang berbahaya untuk perkembangan otak anak [Brenner and Hall, 2007). S100B adalah protein yang bersifat neurotropik, dan kadar dalam serum secara umum meningkat pada populasi anak yang masih mengalami perkembangan otak (Astrand et al, 2012; Berger and Kochanek, 2006). Peningkatan kadar serum S100B ditemukan pada trauma kepala berat sehingga hasil 
Trauma Kepala pada Anak: Klasifikasi Hingga Pemantauan jangka Panjang

Erny, Okky Prasetyo, Denny Prasetyo

tersebut dapat digunakan sebagai faktor prediktor keburukan hasil luaran (Berger et al, 2010). Pasien cedera kepala berat dengan kadar Protein S100B 120 jam pasca trauma yang tinggi, memiliki hasil keluaran yang buruk (Thelin et al, 2017).

Beberapa modalitas pemeriksaan pencitraan saat ini banyak dilakukan pada kasus trauma kepala pada anak misalnya CT scan Kepala dan MRI Kepala. Tentunya ada banyak pertimbangan untuk melakukan pemeriksaan tersebut mengingat risiko radiasi yang dapat mengganggu proses perkembangan otak untuk anak usia $<2$ tahun. CT scan adalah salah satu pemeriksaan radiologis yang masih sering dipakai sampai sekarang. Penggunaan MRI saat ini lebih banyak digunakan karena menunjukkan hasil yang lebih sensitif daripada CT scan, namun karena faktor alat dan biaya, CT scan masih menjadi alat bantu penegakan diagnosa yang utama. CATCH (Canadian Assessment of Tomography for Childhood Head injury) dan PECARN (Pediatric Emergency Care Applied Research Network) adalah beberapa algoritma yang dipakai untuk menentukan penggunaan CT scan pada pasien dengan cedera otak ringan

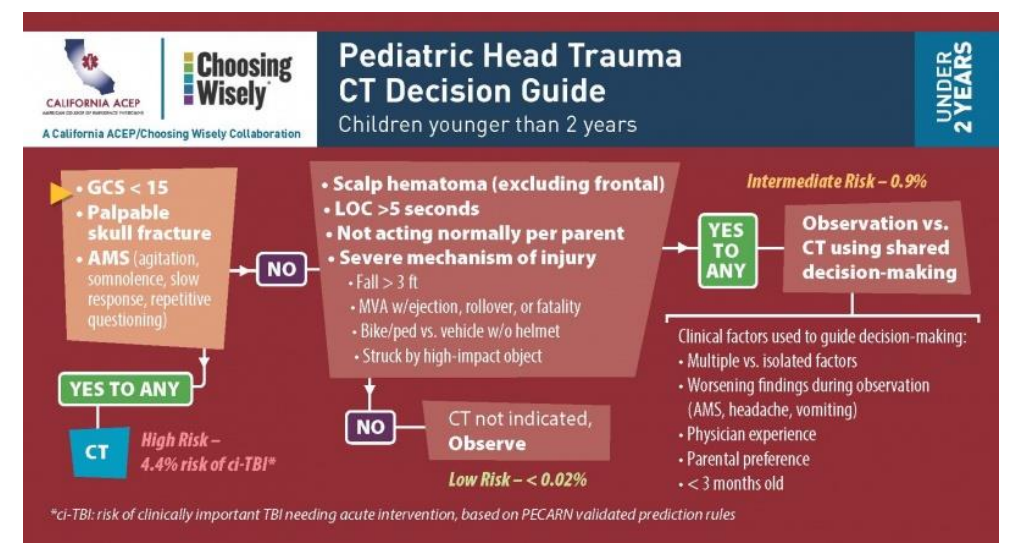

Gambar 1. Panduan pemeriksaan CT scan kepala menurut PECARN pada anak usia $<2$ tahun

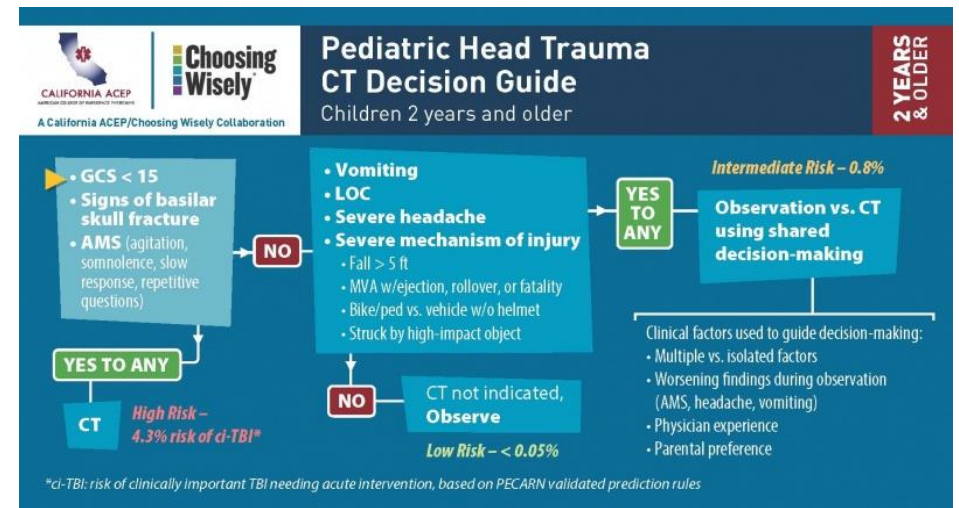

Gambar 2. Panduan pemeriksaan CT Scan kepala menurut PECARN pada anak usia $>2$ tahun 


\begin{tabular}{|c|c|}
\hline \multicolumn{2}{|l|}{$\begin{array}{l}\text { CATCH Rule } \\
\text { Osmond et al. (PERC) CMAJ 2010;182:341-8 }\end{array}$} \\
\hline \multicolumn{2}{|l|}{ CATCH RULE for Childhood Head Injury } \\
\hline \multicolumn{2}{|l|}{ CT of the head is required if: } \\
\hline \multicolumn{2}{|c|}{ HIGH RISK (need for neurologic intervention) } \\
\hline $\begin{array}{l}\text { 1. GCS }<15-2 \text { hours after injury } \\
\text { 2. Suspected open or depressed skull fracture } \\
\text { 3. History of worsening headache } \\
\text { 4. Irritability on examination }\end{array}$ & $\begin{array}{l}\text {-Sensitivity } 100 \% \\
\text {-Specificity } 70.2 \% \\
\text {-Require } 30.2 \% \text { to } \\
\text { undergo CT }\end{array}$ \\
\hline \multicolumn{2}{|l|}{ MEDIUM risk (brain injury on CT scan) } \\
\hline $\begin{array}{l}\text { 5. Any sign of basal skull fracture } \\
\text { 6. Large, boggy hematoma of scalp } \\
\text { 7. Dangerous mechanism of injury }\end{array}$ & $\begin{array}{l}\text {-Sensitivity } 98.1 \% \\
\text { - Specificity } 50.1 \% \\
\text {-Require } 51.9 \% \text { to } \\
\text { undergo CT }\end{array}$ \\
\hline
\end{tabular}

Gambar 3. Indikasi CT Scan kepala merurut Catch rule berdasarkan derajat risiko pada trauma kepala

Kegunaan EEG yang terutama untuk menegakkan diagnosis status epileptikus non konvulsivus yang dapat mengikuti kejadian trauma kepala. Penelitian menunjukkan pada $22 \%$ trauma kepala dapat terjadi manifestasi klinis kejang konvulsi maupun non konvuksi (Vespa et al, 1999, Aquino et al, 2017). Penelitian pada 2012 kasus menunjukkan gambaran EEG dengan perlambatan yang berat dan supresi pada gelombang delta berkaitan dengan keburukan hasil luaran pada 3-6 bulan pada pasien dengan trauma kepala. Meta analisis dari kemampuan EEG sebagai faktor prognostik pada 44 penelitian trauma kepala berat dengan mengekslusi lesi lokal yang nyata, dilakukan dekompresi kraniotomi, atau adanya penumpukan cairan subdural dan ekstradural, hasil EEG berupa tidak ditemukan somatosensory evoke potensial bilateral berkaitan dengan keburukan hasil luaran pada $99.5 \%$ pasien (Carter and Butt, 2001).

\section{PENATALAKSANAAN}

Prinsip penatalaksanaan trauma kepala adalah stabilisasi tanda vital, mempertahankan tekanan intrakranial yang fisiologis dan melakukan koreksi defisit elektrolit, dan parameter-parameter dari hasil pemeriksaan darah lengkap serta mengevaluasi trauma ditempat lain (Pineda et al, 2013).

Stabilisasi tekanan intrakranial dilakukan disamping untuk tatalaksana akut juga untuk mencegah cedera otak sekunder. Cedera otak sekunder terjadi akibat hipoperfusi jaringan otak dan menyebabkan penumpukan hasil metabolisme. Hal ini menyebabkan edema otak dan meningkatkan tekanan intra kranial (Kochaneck al, 2012). Adelson et al 
Trauma Kepala pada Anak: Klasifikasi Hingga Pemantauan jangka Panjang

Erny, Okky Prasetyo, Denny Prasetyo

(2003) mengatakan bahwa cedera kepala dengan GCS $<8$ perlu mempertimbangkan pemasangan alat pengukuran tekanan intracranial, termasuk bayi dengan ubunubun yang masih terbuka. Pada penelitian lain menyatakan bahwa menjaga tekanan perfusi otak antara $40 \mathrm{mmHg}-65 \mathrm{mmHg}$ penting dilakukan untuk mencegah cedera otak sekunder (Adelson et al, 2003).

Terapi konvensional pada cedera otak adalah head up $30^{\circ}$, pencegahan hipotermia/ hipertermia, analgesia, sedasi, terapi hyperosmolar, diuretic, dan intervensi pembedahan lainnya. Head-up $30^{\circ}$ bertujuan menurunkan tekanan intracranial menggunakan prinsip gravitasi. Keuntungan lain dari posisi ini adalah meningkatkan venous return dan memperbaiki distribusi dari cairan cerebro spinal. Beberapa penelitian menunjukkan bahwa posisi horizontal lebih baik untuk menaikkan tekanan perfusi otak (cerebral perfusion pressure), namun posisi horizontal ini cenderung untuk meningkatkan tekanan intra kranial, sehingga dapat memicu cedera otak sekunder.

Penggunaan terapi hyperosmolar mannitol bertujuan menurunkan tekanan intracranial, tetapi karena menyebabkan rebound ischemic effect, hipovolemi akibat diuresis, dan gangguan keseimbangan elektrolit, maka penggunaan mannitol semakin ditinggalkan dan saat ini banyak digunakan cairan yang bersifat hipertonis saline. Hipertonis saline juga meningkatkan volume di pembuluh darah dengan menarik cairan di parenkim otak tetapi memiliki efek diuresis yang lebih rendah.

Penggunaan terapi hipotermia bertujuan untuk menghindari cedera otak sekunder akibat peningkatan metabolisme otak (Kochaneck et al, 2012). Pengembalian suhu tubuh (rewarming) harus dilakukan dengan perlahan $\left(0,5^{\circ} \mathrm{C}\right.$ $1^{\circ} \mathrm{C}$ ) per $3-4$ jam, karena dapat mengakibatkan efek rebound pada peningkatan tekanan intracranial (Adelson, et al, 2005).

Penggunaan

barbiturate (phenobarbital, thiopental) dalam dosis tinggi dapat menurunkan tekanan intracranial, pada saat terapi lain seperti pembedahan tidak efektif. (kochanek, 2012) hal tersebut karena barbiturate menurunkan demand metabolisme dan menurunkan ROS serta lipid peroxide. Tetapi karena barbiturat juga menimbulkan hipotensi, penurunan cardiac output, pemakaian barbiturate biasanya digolongkan pada terapi tingkat ke tiga, apabila terapi -terapi lain dan pembedah tidak bisa dilakukan.

Terapi hiperventilasi merupakan salah satu tatalaksana awal pada pasien dengan tujuan mencegah hipokarbia 
sehingga terjadi vasokonstriksi relatif pembuluh darah otak dengan tujuan akhir menurunkan tekanan intrakranial. Tetapi yang harus dihindari adalah hiperventilasi agresif karena justru akan menyebabkan iskemia dan menyebabkan cedera otak sekunder (kochanek, 2012). Sehingga, para ahli menyarankan bahwa hiperventilasi secara agresif harus dihindari pada 48 jam pertama setelah kejadian trauma. Menurut guideline dari AHA tahun 1992, justru yang harus dilakukan adalah terapi normoventilasi pada kasus cedera otak pada trauma.

Pemberian sedasi dan analgesia berdasarkan prinsip bahwa rasa nyeri dapat meningkatkan demand metabolism dari otak, sehingga dapat menaikkan tekanan intracranial, mual dan muntah juga dapat merangsang saraf simpatis sehingga meningkatkan tekanan darah dan meningkatkan risiko perdarahan pada saat pasca operasi, stress karena nyeri dan tidak nyaman juga dapat memberikan trauma psikologis. Reaksi fisiologis dari terapi, seperti batuk karena pemakaian selang hisap dan menggigil karena terapi hipotermia juga dapat meningkatkan demand metabolism dari otak. Semua reaksi tersebut menjadi dasar diperlukannya obat- obatan sedasi dan analgesic (kochanek, 2012). Penggunaan sedasi untuk cedera otak harus memiliki efek minimal pada kardiovaskuler, memiliki onset dan offset kerja pendek, gampang di titrasi, termetabolisir dengan baik, memiliki efek anti kejang, tidak memiliki metabolit aktif, dan interaksi dengan obatobat lainnya minimal.

Terapi pembedahan tergantung kasus masing-masing. Pembedahan yang dilakukan bertujuan untuk mengatasi masalah bedah murni misalnya fraktur tulang tengkorak atau mengatasi masalah akibat terbentuknya SOP di otak (kochanek, 2012).

\section{PROGNOSIS}

Faktor yang menentukan prognosis adalah usia, mekanisme cedera, skor GCS pediatrik pasca resusitasi, reaktivitas pupil, tekanan darah, tekanan intrakranial pasca resusitasi, durasi gangguan kesadaran, gangguan keseimbangan tubuh dan ukuran dan macam lesi intrakranial.

\section{PEMANTAUAN JANGKA PANJANG}

Pemantauan jangka panjang diperlukan untuk mengevaluasi hasil luaran baik yang bersifat fisik dan disabilitas intelektual. Perlu ditekankan protokol yang bersifat komprehensif, rehabilitasi multidisiplin untuk mempercepat pemulihan dan memfasilitasi kelancaran transisi dari perawatan di rumah hingga anak dapat bersekolah kembali. Perlu 
Trauma Kepala pada Anak: Klasifikasi Hingga Pemantauan jangka Panjang

Erny, Okky Prasetyo, Denny Prasetyo

dikembangkan komunikasi yang intensif dan berkesinambungan antara dokter sepesialis rehabilitasi medik, anggota keluarga dan tenaga pendidik. Kolaborasi tersebut memerlukan kejelasan kelainan fungsi yang terjadi akibat trauma kepala sebelumnya dan diharapkan meningkatkan potensi positif anak pada waktu yang akan datang (Kurihara et al, 2012). Pada penelitian kohort trauma kepala anak dengan skor GCS 3 atau 4, angka mortalitas berkisar 56,6\% pada tahun 1 setelah trauma kepala. Namun sekitar 15\% pasien menunjukkan hasil luaran yang baik pada $>10$ tahun setelah trauma. Respon pupil saat datang di ruang IGD, kejadian hipotermia dan mekanisme trauma kepala memiliki kaitan erat dengan daya hidup dan hasil luaran (Fulkerson et al, 2015). Pemeriksaan Neuroimaging merupakan bagian yang tidak terpisahkan dalam tatalaksana trauma kepala berat pada anak. Pemeriksaan MRI dan H-Magnetic resonance spectroscopy dapat digunakan untuk menentukan beberapa parameter sensitif yang dapat digunakan sebagai faktor prediktor gangguan fungsi neurologi yang bersifat kronik (Suskauer and Huisman, 2009). Pada sebagian besar kasus trauma kepala ringan pada anak tidak menyebabkan efek ikutan jangka panjang, tetapi masalah jangka panjang pada fungsi psikososial mungkin terjadi terutama pada usia prasekolah (Vaca, 2018)

\section{NASEHAT UNTUK ORANG TUA}

Pertolongan pertama yang dilakukan dengan tidak benar dapat memperburuk kondisi bahkan dapat mempercepat perburukan hingga fatal. Hal-hal yang perlu diketahui orang tua sehubungan dengan pertolongan pertama yang benar pada saat terjadi trauma kepala adalah:

- Trauma kepala yang tidak menunjukkan jejas misalnya hematoma baik di kepala atau wajah, tidak ada muntah spontan tanpa provokasi, tidak ada perubahan perilaku anak sehari-hari, tidak ada kejang spontan tanpa provokasi, tidak perlu dirawat di RS tetapi pendampingan dan observasi anak oleh observer yang sama setiap 2-3 jam sekali perlu dilakukan selama 72 jam pasca trauma kepala

- Tirah baring atau pembatasan aktivitas fisik

- Selama masa observasi anak tidak boleh mengkonsumsi obat-obatan yang bersifat sedatif dan anti muntah karena akan menimbulkan efek sublimasi jika gejala muncul

- Jangan diberikan makanan dan minuman yang menimbulkan banyak 
gas dilambung karena akan memicu muntah

Segera dibawa ke RS jika:

- Anak tampak lebih banyak tidur dari kebiasaannya dan lebih sulit dibangunkan

- Perubahan perilaku yang bermakna misalnya mejadi histeria, marah tanpa alasan, atau justru sulit diajak komunikasi

- Muntah tanpa masalah di pencernaan yang terus menerus

- Kejang baik pada wajah atau anggota gerak

- Keluhan sakit kepala yang memberat disertai dengan kaku pada leher

- Tampak keluar cairan atau darah dari telinga, hidung

- Pada bayi atau anak usia <18 bulan jika tampak sulit minum dan ubun-ubun besar membonjol

- Terdapat gangguan gerak misalnya tangan dan kaki tampak lemas untuk bergerak

Pertanyaan yang sering disampaikan pada dokter adalah apakah anaknya akan normal seperti sedia kala setelah trauma kepala. Sebagai dokter seharusnya menyampaikan fakta secara obyektif sesuai dengan temuan secara klinis maupun hasil pemeriksaan penunjang. Hasil-hasil tersebut harus teranalisis dengan gamblang dan mudah dipahami orang tua secara umum mengenai kondisi anaknya. Secara pasti observasi tumbuh kembang wajib dilakukan pasca trauma kepala untuk deteksi dini dan intervensi dini.

\section{DAFTAR PUSTAKA}

Adelson PD, Bratton SL, Carney NA, et al, 2003. Guidelines for the acute medical management of severe traumatic brain injury in infants, children, and adolescents. Chapter 5. Indications for intracranial pressure monitoring in pediatric patients with severe traumatic brain injury. Pediatr Crit Care Med, 4(3 Suppl): S19-24. [PMID:12847341]

Aquino L, Kang CY, Harada MY, Ko A, DoNguyen A, Ley EJ, et al, 2017. Is Routine Continuous EEG for Traumatic Brain Injury Beneficial?. Am Surg, 83 (12):1433-1437

Astrand R, Romner B, Reinstrup P, FriisHansen L, Unden J, 2012. Comparison between capillary, venous and arterial levels of protein S100B in patients with severe brain pathology. Clin Chem Lab Med, 50:1055-1061

Berger S, Schurer L, Hartl R, Deisbock T, Dautermann C, et al, 1994. 7,2\% $\mathrm{NaCl} / 10 \%$ dextran-60 versus $20 \%$ 
Trauma Kepala pada Anak: Klasifikasi Hingga Pemantauan jangka Panjang

Erny, Okky Prasetyo, Denny Prasetyo

mannitol for treatmen intracranial hipertension. Acta Neuroped Suppl(Wien), 60: 494498

Berger RP and Kochanek PM, 2006. Urinary S100B concentrations are increased after brain injury in children: a preliminary study. Pediatr Crit Care Med, 7(6): 557561

Berger RP, Bazaco MC, Wagner AK, Kochanek PM, Fabio A, 2010. Trajectory analysis of serum biomarker concentrations facilitates outcome prediction after pediatric traumatic and hypoxemic brain injury. Dev Neurosci, 32: 396-405

Berksoy EA and Anil M, 2019. Effectiveness of complete blood count parameters for Predicting intracranial injury in children with minor head trauma. Sanamed, 14(1): 59-65

Brain Trauma Foundation; American Association of Neurological Surgeons; Congress of Neurological Surgeons; Joint Section on Neurotrauma and Critical Care, Bratton SL, Chestnut RM, Ghajar J, McConnell Hammond FF, Harris OA, Hartl R, Manley GT, Nemecek A, Newell
DW, Rosenthal G, Schouten J, Shutter L, Timmons SD, Ullman JS, Videtta W, Wilberger JE, Wright DW, 2007. Guidelines for the management of severe traumatic brain injury. I. Blood pressure and oxygenation. J Neurotrauma, 24(suppl 1): S7-13

Brasure M, Lamberty GJ, Sayer NA, Nelson NW, Macdonald R, Ouellette J, Tacklind J, et al, 2012. Multidisciplinary postacute rehabilitation for moderate to severe traumatic brain injury in adults. Agency for Healthcare Research and Quality (AHRQ) Comparative Effectiveness Reviews, 72, ES1-ES20. Available at: http:// effectivehealthcare.ahrq.gov/ehc /products/283/1141/CER72_TBIP ostacute_FinalReport_20120725. pdf

Brenner DJ and Hall EJ, 2007. Computed tomography-an increasing source of radiation exposure. $N$ Engl J Med, 357:2277-2284

Bruce DA, 1996. Pediatric head injury. In Wilkin RH, Rengachary SS, eds. Neurosurgery, $2^{\text {nd }}$ ed. New york, St Louis, San Francisco: McGrawHill, Health Proffesion Devision, pp: $2079-714$ 
ISSN 1978-2071 (Print); ISSN 2580-5967 (Online) Jurnal IImiah Kedokteran Wijaya Kusuma 8(2) : 42-58, September 2019

Carter BG and Butt W, 2001. Review of the use of somatosensory evoked potentials in the prediction of outcome after severe brain injury. Crit Care Med, 29(1):17886

Centers for Disease Control and Prevention, 2003. Report to congress on mild traumatic brain injury in the United States: Steps to prevent a serious public health problem. Atlanta (GA): National Center for Injury Prevention and Control

Centers for Disease Control and Prevention, 2015. Report to conggress on traumatic brain injury in USA: Epidemiology and rehabilitation. Atlanta, GA: Author

Centers for Disease Control and Prevention, 2014. TBI data and statistics.

Ciurea AV, Tascu A, Brehar FM, et al, 2009.

A life threatening problem in infants: supratentorial epidural hematoma. J Med Life. 2(2):191-5

DePompei R, 2010. Pediatric Traumatic brain injury: Where do we go from here? The Asha leader, $15: 16-20$

Fanconi S, Klöti J, Meuli M, et al, 1988 Dexamethasone therapy and endogenous cortisol production in severe pediatric head injury. Intensive Care Med. 14(2):163-6.

Fulkerson DH, White IK, Rees JM, Baumanis MM, Smith JL, Ackerman LL, Boaz JC, Luerssen TG, 2015. Analysis of long-term (median 10.5 years) outcomes in children presenting with traumatic brain injury and an initial Glasgow Coma Scale score of 3 or 4. J Neurosurg Pediatr, 16(4): 410-9

Jeremitsky $\mathrm{E}$, Omert L, Dunham CM, Protetch J and Rodriguez A, 2003. Harbingers of poor outcome the day after severe brain injury: hypothermia, hypoxia, and hypoperfusion. J Trauma, 54:312319

Shi J, Dong B, Mao Y, Guan W, Zhu R ang Wang S, 2016. Review: traumatic brain injury and hiperglycemia, a potentially modifiable risk factor. oncotarget, 7(43): 71052-7061

Kamal HM, Sammou H, Mardini AA, Zaitoni A, 2011. Fall of platelet count in children with traumatic brain injury: is it of value? Chin J Traumatol, 14(6):336-42.

Khanna S, Davis D, Peterson B, et al, 2000. Use of hypertonic saline in the treatment of severe refractory posttraumatic intracranial 
Trauma Kepala pada Anak: Klasifikasi Hingga Pemantauan jangka Panjang

Erny, Okky Prasetyo, Denny Prasetyo

hypertension in pediatric traumatic brain injury. Crit Care Med, 28(4):1144-51.

Kochanek PM, Carney N, Adelson PD, Ashwal S, Bell MJ, Bratton S, et al, 2012. Guidelines for the acute medical management of severe traumatic brain injury in infants, children, and adolescents-second edition. Pediatr Crit Care Med, 13 Suppl 1: S1-82.

Kurihara M, Shishido A, Yoshihashi M, Fujita H, Kohagizawa T, 2012. Prognosis of posttraumatic epilepsy in children. J Jpn Epilepsy Soc, 29: 460- 469

Lippi G, Carbucicchio A, Benatti M, Cervellin G, 2013. The mean platelet volume is decreased in patients with mild head trauma and brain injury. Blood Coagul Fibrinolysis, 24(7): 780-3

Malec JF, Brown AW, Leibson CL, Flaada JT, Mandrekar JN, Diehl NN, and Perkins PK, 2007. The Mayo classification system for traumatic brain injury severity. Journal of Neurotrauma, 24(9), 1417-1424

Kastilong M, Subrata I, Tangkudung G, Khosama H, 2018. Rasio neutrofil limfosit dan luaran cedera kepala. J sinaps, 1(2): 20-28
Mihic J, Rotim K, Marcikic M, Smiljanic D, 2011. Head Injury in Children. Acta Clin Croat, 50(4):539-548

Mitra B, Cameron P, Butt Warwick, 2007. Population-based study of paediatric head injury. $J$ of Paed and child Health, 43(3): 154-159

Pineda JA, Leonard JR, Mazotas IG, Noetzel M, Limbrick DD, et al, 2013. Effect of implementation of paediatric neurocritical care programme on outcome after severe traumatic brain injury: a retrospective cohort study. Lancet Neurol, 12(1): $45-52$

Rovlias A and Kotsou S, 2000. The influence of hyperglycemia on neurological outcome in patients with severe head injury. Neurosurgery, 46: 335-342

Rovlias A and Kotsou S, 2001. The Blood Leucocyte count and its prognostic significance in severe head injury. Surg Neurol, 55(4): 190-6

Seyed Saadat SM, Bidabadi E, Seyed Saadat $\mathrm{SN}$, Mashouf $\mathrm{M}$, Salamat $\mathrm{F}$ and Yousefzadeh S. Association of persistent hyperglycemia with outcome of severe traumatic brain injury in pediatric population. Childs Nerv Syst. 28(10): 1773-1777 
ISSN 1978-2071 (Print); ISSN 2580-5967 (Online) Jurnal IImiah Kedokteran Wijaya Kusuma 8(2) : 42-58, September 2019

Song SS and Lyden P, 2013. Overview of therapeutic hypotermia. Curr Treat Options Neurol, 14(6): 541548

Silvia DV, Linda WX, Juliet N, Christine $\mathrm{M}$, Benjamin $\mathrm{JL}$, Joel $\mathrm{K}$, et $a l$, 2018. Long-term follow-up of pediatric head trauma patients treated at Mulago National Referral Hospital in Uganda. $J$ of Neurosurg, 23:1-133.

Suman S, Kumar N, Singh Y, Kumar V, et al, 2016. Evaluation of serum electrolytes in TBI patients: prospective randomized observational study. J of Anes and Crit Care. 5(3): 1-6

Suskauer SJ, Huisman TA, 2009. Neuroimaging in pediatric traumatic brain injury: current and future predictors of functional outcome. Dev Disabil Res Rev, 15(2): 117-23
Thelin EP, Nelson DW, Bellander BM, 2017. A review of the clinical utility of serum S100B protein level in the assessment of traumatic brain injury. Act Neurochir, 159:209-25

Turfan M, Erdogan E, Ertas G, Duran M, Murat SN, Celik E, et al, 2013. Usefulness of mean platelet volume for predicting stroke risk in atrial fibrillation patients. Blood Coagul Fibrinolysis, 24(1): $55-8$

Vespa PM, Nuwer MR, Nenov V, RonneEngstrom E, Hovda DA, et al, 1999. Increased incidence and impact of nonconvulsive and convulsive seizures after traumatic brain injury as detected by continuous electroencephalographic monitoring. J Neurosurg, 91(5):750-60 